\title{
Exploring the Relationship between Employability and College's Curriculum from the Perspective of Graduates
}

\author{
Jing Wang \\ Neusoft Institute, Guangdong \\ Nanhai Information Technology Park \\ Foshan, Guangdong \\ wj@neusoft.com
}

\begin{abstract}
Graduates' employability is the hot issue attracting the attention of the state and society. We explore the relationship between the employability and college's curriculum from the perspective of graduates. As well, it also prompts the corresponding policies and suggestions. Research results play an important role in college educational reform and reinforcing the employability of the undergraduates.
\end{abstract}

Keywords-employability; college's curriculum; graduates; undergraduates; educational reform

\section{INTRODUCTION}

The national 12th Year Plan proposed the Employment Preference Strategy which insisted the promoting employment on the preference position in the economic and social development. Undergraduates are the previous talent resource for our country. Their employabilities are related to the implement of the strategy of rejuvenating the country through science and education, and strategy of reinvigorating China through human resource development, which extremely attract the national and social attention. According to the reports, in 2014 , the number of the national ordinary college graduates reached 7.27 million. In 2015, it increased by 7.49 million. And to 2016, it will increase. The graduates' employment spring won't come and they still face severe employment situation $^{1}$. How to cultivate and improve their employability becomes the important policy to solve the problem. In the research on promoting the undergraduates' employability, the main parts concentrate on the undergraduates' employment from the point of enterprises [1][4]. However, they didn't take the graduates into consideration. The relative research data shows that contemporary college undergraduates are weary of studying, lack the clear study goal. $60 \%$ students do not like their majors and even 6\% students do not have preferable major or do not like any majors [5]. Aiming at the problem, we make the research on the graduates to know how they view the relationship between the employability and college's curriculum. Then, we propose the relative policies and suggestions for these problems and provide the reference for the college educational reform and reinforcing the employability of the undergraduates.

\section{RESEARCH SAMPLES AND CONTENTS}

We selected the graduates of Guangdong province and made the interviews to them. According to the interviews, we designed the questionnaire and issued 200 questionnaires, returned 195 . The real return rate is $97.5 \%$. The male participants are more, reaching $75.38 \%$. The main contents include the rational college's curriculum, relation to employability, the compulsory knowledge and ability, and assistance what they want to improve the employability.

\section{RESEARCH FINDINGS}

\section{A. Graduates Believe That the Arrangement of Practical Curriculum Is Irrational}

In this research, we divided the undergraduate courses into three classifications: quality educational curriculum, professional educational curriculum and practical curriculum. The quality educational curriculum means that the cultural quality course or general education curriculum, such as College Chinese, College English and Basis of Computer Engineering [1]. The research on the rational curriculum arrangement results shows in the Fig. 1 . About $44.62 \%$ graduates believe that the practical curriculum is the most irrational. The next is the professional educational curriculum and quality educational curriculum, respectively $29.23 \%$ and $18.46 \%$. And $7.69 \%$ students select others.

Through the statistics on the improvement of college curriculum arrangement, as shown in TABLE I, it finds that the graduates prefer to increase the practical courses, occupying $75.90 \%$. The next is professional educational course, accounting for $45.13 \%$. Then, about $44.62 \%$ graduates prefer to increase the innovative and entrepreneurship courses. 8.72\% graduates select to reduce the quality educational courses and $8.21 \%$ graduates select others.

\footnotetext{
${ }^{1}$ http://www.xuexila.com/zhichang/guihua/295568.html
} 


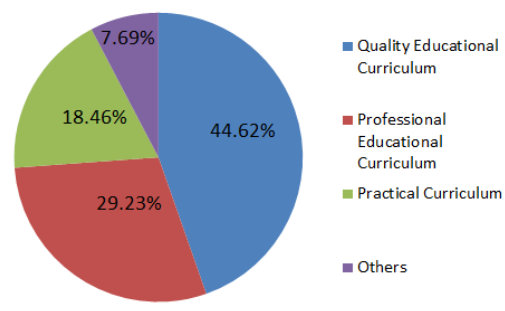

Fig. 1. Most Irrational Type of College Curriculum Arrangement

TABLE I. IMPROVEMENT FOR COLLEGE CURRICULUM ARRANGEMENT

\begin{tabular}{|c|c|c|}
\hline Selections & Frequency & Percentage \\
\hline Increase the Practical Courses & 148 & $75.90 \%$ \\
\hline $\begin{array}{c}\text { Increase Professional } \\
\text { Educational Courses }\end{array}$ & 88 & $45.13 \%$ \\
\hline $\begin{array}{c}\text { Increase the Innovative and } \\
\text { Entrepreneurship Courses }\end{array}$ & 87 & $44.62 \%$ \\
\hline $\begin{array}{c}\text { Reduce the Quality } \\
\text { Educational Courses }\end{array}$ & 17 & $8.72 \%$ \\
\hline Others & 16 & $8.21 \%$ \\
\hline
\end{tabular}

TABLE II.

IMPROVING COLLEGE’S CURRICULUM TEACHING IN TURN

\begin{tabular}{|c|c|c|}
\hline Selections & Frequency & Percentage \\
\hline Stressing the Practical Teaching & 148 & $75.90 \%$ \\
\hline $\begin{array}{c}\text { Cultivating the Undergraduates’ } \\
\text { Professional Abilities }\end{array}$ & 126 & $64.62 \%$ \\
\hline $\begin{array}{c}\text { Innovating the Teaching } \\
\text { Methods }\end{array}$ & 101 & $51.79 \%$ \\
\hline $\begin{array}{c}\text { Training the Undergraduates’ } \\
\text { Employment Concept }\end{array}$ & 87 & $44.62 \%$ \\
\hline $\begin{array}{c}\text { Reforming the Curriculum } \\
\text { Textbook }\end{array}$ & 52 & $26.67 \%$ \\
\hline
\end{tabular}

Research finds that the graduates hope improving college's curriculum teaching in turn: (1) stressing the practical teaching (2) cultivating the undergraduates' professional abilities (3) innovating the teaching methods (4) Training the undergraduates' employment concept (5) reforming the curriculum textbook, as shown in TABLE II.

\section{B. Graduates believe that college's curriculum do little to help working}

In the research, we find that $61.03 \%$ graduates believe that they will work related to their majors which means they are really interested in their majors. But, as shown in Fig.2, $57.44 \%$ graduates believe that during the college period, the curriculum provide the general assistance to their future career. As shown in Fig.3, 66.15\% graduates believe that the grade just has general influence on the future career.

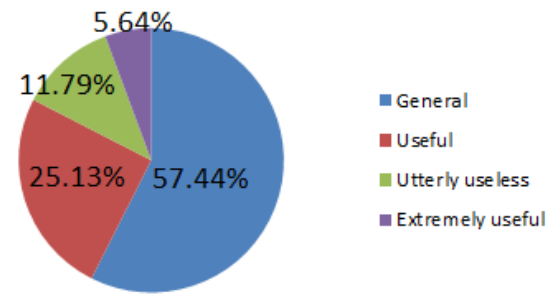

Fig. 2. Graduates's view that college's curriculum help employing

Shown as in TABLE III, the graduates believe that the importance of employabilities in turn is: (1) interpersonal ability (2) communication and expression skills (3) ability of solving the problems (4) self-management ability (5) strain and innovative skills (6) relative professional abilities (7) team working ability (8) professional cognitive skill (9) leading capability. On the other hand, as the TABLE IV, the graduates think that the employment influence factors in turn are:

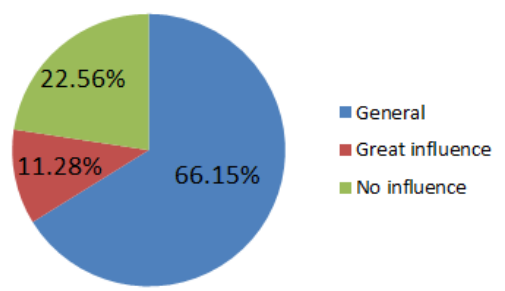

Fig. 3. Graduates's view that academic records influence on employing

TABLE III. IMPORTANCE OF EMPLOYABILITY LEARNED IN COLLEGE

\begin{tabular}{|c|c|c|}
\hline Importance of Employability & Frequency & Percentage \\
\hline Interpersonal Ability & 136 & $69.74 \%$ \\
\hline $\begin{array}{c}\text { Communication and Expression } \\
\text { Skills }\end{array}$ & 136 & $69.74 \%$ \\
\hline Ability of Solving the Problems & 118 & $60.51 \%$ \\
\hline Self-managementAbility & 113 & $57.95 \%$ \\
\hline Strain and Innovative Skills & 107 & $54.87 \%$ \\
\hline Relative Professional Abilities & 104 & $53.33 \%$ \\
\hline Team Working Ability & 100 & $51.28 \%$ \\
\hline Professional Cognitive Skill & 97 & $49.74 \%$ \\
\hline Leading Capability & 56 & $28.72 \%$ \\
\hline
\end{tabular}


TABLE IV. EMPLOYMENT INFLUENCE FACTORS

\begin{tabular}{|c|c|c|}
\hline Employment influence factors & Frequency & Percentage \\
\hline Practical Experience Deficiency & 158 & $81.03 \%$ \\
\hline $\begin{array}{c}\text { Incomplete Professional } \\
\text { Knowledge }\end{array}$ & 154 & $78.97 \%$ \\
\hline Communication Ability & 82 & $42.05 \%$ \\
\hline $\begin{array}{c}\text { Strain and Anti-pressureAbility } \\
\text { High Requirement for } \\
\text { Workings }\end{array}$ & 70 & $35.90 \%$ \\
\hline Family Background & 22 & $21.54 \%$ \\
\hline Others & 3 & $1.54 \%$ \\
\hline
\end{tabular}

(1) practical experience deficiency (2) incomplete professional knowledge (3) communication ability (4) strain and anti-pressure ability (5) high requirement for workings (6) family background (7) others. It follows that the graduates believe the major reasons for their employment are lacking practical experience and incomplete professional knowledge. The result shows that the professional educational courses generate the larger influence for the undergraduates but the professional skills are clearly deficient. On the other hand, we also find that during the college period, the undergraduates are stressing the practice but ignoring the theoretical knowledge.

\section{Graduates Hope the College Offer Profession-Oriented Curriculum}

According to the research, as TABLE V, the graduates believe that recently, the reasons for low employment rate in turn are: (1) large number of undergraduates (2) high personal expectation (3) high demand of talents (4) low average salary

TABLE V. REASONS FOR LOW EMPLOYMENT RATE

\begin{tabular}{|c|c|c|}
\hline Reasons for Low Employment Rate & Frequency & Percentage \\
\hline Large Number of Undergraduates & 130 & $66.67 \%$ \\
\hline High Demand of Talents & 120 & $61.54 \%$ \\
\hline Low Average Salary & 119 & $61.03 \%$ \\
\hline Less Working Positions & 93 & $47.69 \%$ \\
\hline Others & 74 & $37.95 \%$ \\
\hline
\end{tabular}

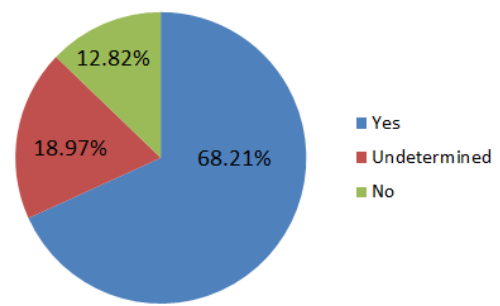

Fig. 4. Whether they will participate in the profession-oriented curriculum

(5) less working positions (6) others. Hence, the graduates can objectively treat the serious employment issue and find the reasons from themselves. When they are asked whether they will participate in the profession-oriented curriculum, $68.21 \%$ graduates select “yes”, showing as Fig.4. Only $12.82 \%$ graduates select "no" and other $18.97 \%$ graduates select undetermined. It can be seen that over half graduates hope the college offer the profession-oriented curriculum.

D. Over half graduates believe that enlarging the friend circle could make up with the deficiency of working experience

Surprising, over half graduates believe that enlarging the friend circle could make up with the deficiency of working experience, holding $61.54 \%$. Then is the versatility and participating in more social organization, respectively $49.23 \%$ and $47.18 \%$. Only $43.08 \%$ graduates believe that learning college's curriculum could make up with the deficiency of working experience. $11.28 \%$ students select others. Through the interview, we find that contemporary undergraduates prefer the social networking service, such as WeChat, through which the undergraduates could know the related consultation including the rehiring information, recruitment requirement and salary treatment. Even in the working issues, they can find solution through the social networking service.

TABLE VI. MAKE UP WITH THE DEFICIENCY OF WORKING EXPERIENCE

\begin{tabular}{|c|c|c|}
\hline Selections & Frequency & Percentage \\
\hline Enlarging the Friend Circle & 120 & $61.54 \%$ \\
\hline Versatility & 96 & $49.23 \%$ \\
\hline $\begin{array}{c}\text { Participating in More Social } \\
\text { Organization }\end{array}$ & 92 & $47.18 \%$ \\
\hline Learning College's Curriculum & 84 & $43.08 \%$ \\
\hline Others & 22 & $11.28 \%$ \\
\hline
\end{tabular}

\section{RESEARCH CONCLUSIONS AND SUGGESTIONS}

\section{A. Improving Quality Education Course and Stressing the Comprehensive Quality Cultivation}

With the development of high education, improving the undergraduate's comprehensive qualities becomes the important mission of contemporary college education. In the open questions of the questionnaire, most graduates mention to reinforce the humanistic qualities and lead the students to read more books. There into, it also prompts to reinforce the undergraduates' psychological quality education and to cultivate the undergraduates who are good for the state, society and themselves. At present, most college quality educational courses do not set the clear educational target. Course contents are boring, and especially there are low attendance rate and low satisfy for quality educational courses. Hence, in order to improve the comprehensive quality of undergraduates, they should perfect the quality educational courses including increasing the general education curriculum and reform the curriculum contents and teaching methods, according to the current social requirement for employment. In the implement of quality educational courses, more attention should be paid to cultivate the real interpersonal ability, solving the problems skills, communication and expression skills, self-management skills, strain and innovative ability, team working ability, processional cognitive ability and leaders' cultivation ability. In addition, the quality educational 
courses should associate with the professional courses, which can make undergraduates construct the integrated knowledge structure and general ability system.

\section{B. Strengthen the Construction of Teaching Staff and Emphasize Theoretical Curriculum Design and Skill Cultivation}

Currently, it is universe that ignoring the theories but stressing the practices in college period for undergraduates. There are low attendances for professional theories courses, lack of concentration in the class and serious skipping classes. When participating in the work, graduates find out that their professional theories and knowledge aren't enough to be qualified the current working position. Thus, the college should correctly lead the undergraduates to learn professional knowledge and cultivate the professional skills. In order to do that, the teachers not only have higher theoretical knowledge but also strong ability of professional practice. Thus, we need to build high teaching level and strong ability of professional practice "double type" teachers [2]. The college should know the specific requirement of the enterprise to the talents, integrate the position abilities into the professional abilities cultivation and manufacture scientifically the teaching plan. The design for theoretical courses should show the professional structure, core knowledge units and knowledge points. During the teaching period, they should put the theories into practice, adopt multiple teaching methods and strengthen the skilloriented technical teaching.

\section{Reinforcing the Practical Courses Ratio and Improving the Practical Curriculum System}

From the point of graduates, the practical courses should be increased. The practical courses are necessary for improving the graduates' professional skills. Scientific, rational and enough practical courses are one of the necessary conditions to cultivate the qualified talents. The poor practice ability of the graduates is a long-term problem. Practical courses are the important factor to enforce the undergraduates' employability. Undergraduates believe that their employabilities are deficient and hope to increase of practical courses, which show the importance and emergency for the practical curriculum. With the increasing of employment pressure, the practical experience plays great role in the employment competition. According to report, in 2016, there are over million examinees give up the college entrance examination, occupying $10 \%$. The main reasons are study abroad, high tuition and difficult employment ${ }^{2}$. In recent years, a large part of candidates give up college entrance examination initiative, but choose to study abroad. The major reason is college value is too low, and the quality is uneven. If the college education and curriculum could not improve the employability and human cost, the value of college education will be doubted. The college curriculum should be changed and optimized according to the change of market and undergraduates' requirements. From the research results, the college practical courses have their own randomness and do not form the integrated curriculum system. The college practical course system should show the requirements of cultivation target for the ability structure, and

\footnotetext{
${ }^{2}$ http://mt.sohu.com/20160607/n453408328.shtml
}

decide every target structure and specific indication through the ability structure [3].

\section{Offer the Career-oriented Courses and Reinforce the Professional Cognitive Education}

College undergraduates' employability is a key to the success of employment. Their employability is gained by exploring the study and comprehensive qualities so that they will improve the self-value in the society. The college's curriculum plays a critical role in cultivate college undergraduates' employability. For the serious information asymmetry between the college entrance examination and signing up for an examination, they do not know the registered major and lack the general understanding for their future career. Because of lacking the professional cognitive, the undergraduates' professional study and accumulation don't keep in line with the career development. Currently, most graduates' careers have little or even no relationship to their majors, which are caused by lacking the professional cognitive. As well, professional cognitive deficiency is also the important cause leading to the professional education dissatisfy the career development. Career-oriented is that undergraduates strive to make themselves to meet the professional requirement based on their interests and future career expectation. The relative research results find that the main reason for undergraduates tiring of studying is the lack of the insider drive force. They don't have the clear target and lack aspiration. Hence, the college should offer career-oriented courses as soon as possible to make they know the career requirements, and establish the professional target, so as to lead them in the college period to learn the professional knowledge and skills legitimately.

\section{CONCLUSION}

To sum up, the influence factors of graduates' employability are multi-aspects, including the reasons of undergraduates themselves and colleges' curriculum. In order to improve employability, undergraduates should establish professional consciousness; strive to learn professional knowledge and practical professional skills. As for colleges, should optimize the curriculum according to the change of market and undergraduates' requirements, especially reinforce the practical courses and offer career-oriented courses.

\section{ACKNOWLEDGMENT}

This work is supported by 2014 Scientific Research Fund project of Guangdong Neusoft Institute (NN140412).

\section{REFERENCES}

[1] Z.F. Sun, X. Wang, S.M. yu. "Exploring the adjustment strategies of college's curriculum to promote the employability”. Tsinghua Journal of Education, Vol. 34, No.4, pp.109-113, August 2013 (In Chinese)

[2] Z.J. Qu, R.L. Wang, S.L. Sun, X.H. WU. "Research on training mode of high-skilled applied talents of CNC technology in application-oriented university”. University Education, pp. 146-147, September, 2015(In Chinese)

[3] F.R. Meng, J. Jia, X.W. Wang. "Construct and Implement innovative practical curriculum system in the network engineering major". Computer Education, No.14, pp. 104-108, July, 2013(In Chinese) 
[4] J.B. Wang, F.F. Wang. "Exploring the employability from the perspective of employers". Modern University Education, No.4, pp. 8792, 2011(In Chinese)

[5] S. Du. "Analyze and suggest study-weariness of undergraduates" Chinese Extra-school Education, No. 11, pp. 12-13, 2014(In Chinese) 